\title{
Aplikasi fosfin formulasi cair terhadap Thrips parvispinus Karny (Thysanoptera: Thripidae) pada bunga potong krisan
}

\author{
Application of liquified formulation phosphine against \\ Thrips parvispinus Karny (Thysanoptera: Thripidae) \\ on cut flowers of Chrysanthemum
}

\author{
Taufan Tanto Setyawan ${ }^{1,2}$, Idham Sakti Harahap ${ }^{2}$, Dadang ${ }^{2}$ \\ ${ }^{1}$ Balai Uji Terap Teknik dan Metode Karantina Pertanian \\ Jalan Raya Kampung Utan-Setu, Desa Mekar Wangi, Kec. Cikarang Barat, Bekasi 17520 \\ ${ }^{2}$ Departemen Proteksi Tanaman, Fakultas Pertanian, Institut Pertanian Bogor \\ Jalan Kamper, Kampus IPB Dramaga, Bogor 16680
}

(diterima September 2014, disetujui Maret 2015)

\begin{abstract}
ABSTRAK
Krisan (Chrysanthemum indicum) merupakan salah satu komoditas hortikultura yang mempunyai peluang sangat besar sebagai sumber devisa negara. Volume ekspor bunga potong krisan Indonesia cenderung terus meningkat. Namun di lapangan, Thrips parvispinus Karny (Thysanoptera: Thripidae) sering menginfestasi bunga potong krisan sehingga hal ini akan menurunkan kualitas bunga dan dapat menghambat kegiatan ekspor bunga potong krisan karena dapat mengurangi pemenuhan persyaratan kesehatan tumbuhan negara pembeli/pengimpor. Untuk mengatasi hal ini maka diperlukan perlakuan karantina yang efektif. Fumigan fosfin formulasi cair diharapkan dapat memenuhi persyaratan perlakuan karantina negara pengimpor. Tujuan penelitian untuk menentukan konsentrasi dan waktu papar aplikasi fumigan fosfin formulasi cair yang efektif terhadap T. parvispinus pada bunga potong krisan dan mengevaluasi kualitas bunga potong krisan akibat perlakuan fumigan fosfin. T. parvispinus dipaparkan fosfin cair pada 9 konsentrasi fosfin cair $(0,25,50,75,100,125,150,175$, dan 200 ppm) dan 3 waktu papar (1, 3, dan 6 jam). Kemudian, dilakukan uji validasi konsentrasi dan waktu papar yang efektif dan evaluasi kualitas bunga potong krisan akibat perlakuan fumigan fosfin. Hasil penelitian menunjukan bahwa aplikasi fosfin cair pada konsentrasi 200 ppm dengan waktu papar 1 jam efektif menyebabkan mortalitas 100\% $T$. parvispinus pada bunga potong krisan. Pada konsentrasi tersebut bahkan hingga waktu papar 6 jam tidak menimbulkan kerusakan fisik atau kelayuan pada bunga potong krisan (kualitas bunga tetap baik).
\end{abstract}

Kata kunci: fumigan, fumigasi, konsentrasi, waktu papar

\begin{abstract}
Chrysanthemum (Chrysanthemum indicum) as one of horticultural commodities has a good prospect to be developed as source of country revenue. The export of cut flowers of chrysanthemum from Indonesia tends to increase year by year. However, Thrips parvispinus Karny (Thysanoptera: Thripidae) which is major insect pest of chrysanthemum often attacks this flower in the field until postharvest causing the decrease of quality of flowers. The poor quality of cut flowers of chrysanthemum including the presence of $T$. parvispinus will be rejected by foreign businesses.
\end{abstract}

\footnotetext{
*Penulis korespondensi: Dadang. Departemen Proteksi Tanaman, Fakultas Pertanian, Institut Pertanian Bogor, 
Therefore, control measures of this insect pest by quarantine officers are important. Treatment can be done using liquified formulation phosphine fumigant. The objectives of this study were to determine the concentration of liquified formulation phosphine and exposure time which will were effectively kill T. parvispinus and to evaluate the quality of cut flowers of chrysanthemums treated with phosphine fumigant. T. parvispinus was exposed to liquied formulation phosphine at 9 concentrations $(0,25$, $50,75,100,125,150,175$ and $200 \mathrm{ppm})$ with 3 exposure times (1, 3, and 6 hours). Moreover, validation test of concentration nd exposure time of liquified formulation phosphine on cut flowers of chrysanthemum was conducted to evaluate the quality of chrysanthemum cut flowers of treated with phosphine fumigant. Results showed that liquified formulation of phosphine at concentration of $200 \mathrm{ppm}$ and on 1 hour of exposure time completely killed T. parvispinus by $100 \%$ mortality. At 200 ppm and exposure time until 6 hours did not affect the quality of cut flowers of chrysanthemum.

Key words: concentration, exposure time, fumigant, fumigation

\section{PENDAHULUAN}

Bunga potong termasuk bunga krisan, merupakan komoditas hortikultura yang pertumbuhan ekspornya semakin meningkat dan mempunyai prospek yang baik sebagai sumber devisa negara. Total volume ekspor bunga potong krisan Indonesia tahun 2012 ke beberapa tujuan negara mencapai 50,92 ton setara dengan US \$1.031.511 (BPS 2013). Volume ekspor tanaman hias Indonesia khususnya bunga potong krisan masih relatif rendah bila dibandingkan dengan negara lain. Malaysia sebagai negara eksportir bunga potong krisan terbesar mencapai 94,22\% atau setara dengan 41523,312 ton dari total ekspor bunga potong krisan segar negara ASEAN sebesar 44071,035 ton (Pusdatin 2014). Bunga potong krisan banyak digemari karena memiliki keragaman dalam hal penampilan, bentuk dan warnanya. Kesinambungan produksi komoditas ini baik dari segi kualitas maupun kuantitas harus diperhatikan dengan baik agar dapat memasuki pasar luar negeri yang semakin kompetitif. Hal ini disebabkan oleh adanya beberapa kendala diantaranya adalah terbawanya organisme pengganggu tumbuhan (OPT) pada bunga yang diekspor. OPT yang sering menyerang bunga krisan diantaranya adalah thrips, Thrips parvispinus Karny (Thysanoptera: Thripidae) yang merupakan salah satu hama utama tanaman krisan. Trips dikenal sebagai hama yang sulit dikendalikan karena ukurannya yang kecil dan perilakunya yang tidak terlalu mudah diketahui. Serangan hama trips dapat menurunkan kualitas bunga krisan (Laksanawati 1996). Dalam era perdagangan bebas, negara pengekspor perlu memperhatikan kesehatan dan kualitas bunga potong yang akan diekspor ke luar negeri, seperti bebas dari organisme penganggu tumbuhan karantina (OPTK).

Fumigasi sebagai perlakuan karantina tumbuhan bertujuan untuk membebaskan media pembawa dari serangga dan tungau dengan gas racun. Fumigasi merupakan cara yang sangat luas dilakukan dalam kegiatan karantina, baik pada produk buah, sayuran maupun tanaman hias. Keunggulan fumigasi diantaranya dapat dilakukan pada komoditas dalam jumlah besar secara bersamaan sehingga dapat menghemat waktu (Barantan 2013). Fumigan metil bromida $\left(\mathrm{CH}_{3} \mathrm{Br}\right)$ memiliki keefektifan paling baik, namun penggunaanya telah dibatasi karena sifatnya yang dapat merusak lapisan ozon (Maha 1997). Sementara itu, fumigan fosfin formulasi padat memerlukan waktu papar yang cukup lama dan beresiko apabila diaplikasikan pada komoditas dengan kadar air yang tinggi (Barantan 2013). Untuk itu, perlu dicari alternatif fumigan yang memiliki keefektifan yang lebih baik dan tidak menimbulkan dampak negatif bagi komoditas yang difumigasi, manusia, hewan, dan lingkungan. Salah satu alternatif fumigan yang mulai banyak digunakan adalah fosfin formulasi cair (gas bertekanan tinggi di dalam tabung).

Di Cili, fosfin telah digunakan untuk pengendalian hama pascapanen pada temperatur rendah pada berbagai buah segar dan sayuran (Horn et al. 2005). Menurut Karunaratne et al. (1997) fosfin pada konsentrasi $600 \mathrm{ppm}$ dan suhu $20{ }^{\circ} \mathrm{C}$ selama 2 jam efektif dalam mengendalikan Heliothrips haemorrhoidalis (Bouché). Sementara itu, perlakuan fumigasi pada konsentrasi $\geq 250 \mathrm{ppm}$ dan waktu papar $\geq 18$ jam pada suhu $2{ }^{\circ} \mathrm{C}$ efektif dalam mengendalikan Frankliniella occidentalis (Pergande). Fumigasi pada konsentrasi 1000 ppm 
dan suhu $2{ }^{\circ} \mathrm{C}$ tidak menyebabkan kerusakan pada selada dan brokoli, kemudian perlakuan fumigasi pada 500 dan 1000 ppm tidak menyebabkan kerusakan atau aman untuk stroberi (Liu 2008).

Sekarang ini tersedia fumigan fosfin dalam formulasi cair. Menurut Barantan (2013), fosfin formulasi cair dengan komposisi $2 \%$ fosfin dan $98 \%$ $\mathrm{CO}_{2}$ sebagai carier, efektif untuk mengendalikan berbagai serangga pada konsentrasi 200-1.000 ppm bergantung pada jenis serangga dan tempat fumigasi dilakukan. Namun demikian, hingga saat ini belum diketahui konsentrasi dan waktu papar yang efektif untuk pengendalian T. parvispinus pada bunga potong krisan di Indonesia pada kisaran suhu antara $26-35{ }^{\circ} \mathrm{C}$ dan pengaruhnya terhadap kualitas bunga potong krisan. Penelitian ini bertujuan untuk menentukan konsentrasi fosfin formulasi cair dan waktu papar yang efektif sebagai fumigan terhadap T. parvispinus pada bunga potong krisan dan mengevaluasi kualitas bunga potong krisan yang diperlakukan fumigan fosfin cair.

\section{BAHAN DAN METODE}

Penelitian dilaksanakan di Laboratorium Entomologi dan Gedung Workshop Fumigasi dan X-Ray di Balai Uji Terap Teknik dan Metoda Karantina Pertanian, Bekasi. Penelitian dilakukan mulai dari bulan November 2013 hingga Juni 2014.

\section{Perbanyakan T. parvispinus}

Metode perbanyakan T. parvispinus dilakukan berdasarkan Helen \& Glenys (2009) dengan sedikit modifikasi pada pakan, yaitu pergantian pakan mentimun dengan buncis. Perbanyakan dilakukan dengan cara mengumpulkan trips yang ditemukan pada tanaman krisan di lapangan dan bunga potong krisan, kemudian dilakukan identifikasi untuk memastikan bahwa serangga yang akan diuji adalah T. parvispinus. Imago trips dipelihara pada kotak perbanyakan hingga menghasilkan telur, nimfa, pupa, dan imago.

\section{Uji aplikasi fumigan fosfin cair}

Pengujian diawali dengan uji pendahuluan untuk menentukan kisaran waktu papar minimal yang diperlukan dalam pelaksanaan perlakuan fumigasi dengan kombinasi konsentrasi fosfin cair yang dapat menyebabkan mortalitas T. parvispinus sebesar $100 \%$ atau kurang. Berdasarkan uji pendahuluan maka ditetapkan konsentrasi waktu papar untuk perlakuan. Sebanyak 25 imago $T$. parvispinus dipaparkan fosfin cair pada 9 perlakuan konsentrasi fosfin cair $(0,25,50,75,100,125,150$, 175, dan 200 ppm) dan 3 waktu papar (1, 3, dan 6 jam). Perlakuan disusun berdasarkan rancangan acak lengkap (RAL) dengan 3 ulangan.

Seluruh tahapan perlakuan dilakukan pada gelas cangkir plastik yang berisi buncis sebagai pakan dan ditempatkan dalam kotak fumigasi (fumigation chamber) yang berukuran $0,75 \mathrm{~m} \mathrm{x}$ $0,75 \mathrm{~m} \times 0,75 \mathrm{~m}$.

\section{Uji validasi fumigan fosfin cair dan evaluasi kualitas bunga potong krisan}

Uji validasi dilakukan pada kombinasi waktu papar dan konsentrasi dari hasil terbaik pada perlakuan sebelumnya dan ditambah 1 konsentrasi diatasnya untuk menjaga kemungkinan adanya penyerapan gas fosfin formulasi cair oleh bunga potong. Pada uji validasi dan evaluasi kualitas bunga potong krisan ini dilakukan 4 perlakuan konsentrasi $(0,174,250$, dan $200 \mathrm{ppm})$ dengan 3 waktu papar (1, 3, dan 6 jam). Perlakuan disusun berdasarkan RAL dengan 3 ulangan.

Perlakuan diujikan pada masing-masing 1 ikat bunga potong krisan (terdiri atas 10 bunga potong) dan pada setiap ikat bunga potong diinfestasikan 25 individu imago T. parvispinus. Bunga potong ditempatkan pada kotak kertas yang ditutup kain kassa. Setelah aplikasi fosfin formulasi cair, dilakukan penghitungan mortalitas T. parvispinus dan pengamatan kualitas fisik bunga potong krisan. Bunga potong ditempatkan dalam ember yang berisi air dan diamati performa/penampilan fisik bunga khususnya kesegaran bunga atau kelayuan bunga akibat fumigasi pada 1, 24, 48, dan 72 jam setelah perlakuan (JSP). Pengamatan kualitas fisik bunga ini dilakukan dengan teknik skoring berdasarkan Smith (1989), sebagai berikut:

$0=$ tidak terjadi kerusakan (bunga sehat/segar);

$1=$ kerusakan 1-25\% (bunga layu sebagian);

$2=$ kerusakan 26-50\% (bunga layu sebagian hingga setengahnya);

3 = kerusakan $51-75 \%$ (bunga layu hampir seluruhnya);

4 = kerusakan $76-100 \%$ (bunga layu seluruhnya hingga mati). 


\section{Analisis data}

Perbedaan mortalitas trips antar perlakuan dianalisis menggunakan Uji Tukey pada taraf 5\%. Analisis probit dilakukan menggunakan program POLO PC (LeOra Software 1987).

\section{HASIL}

Pengaruh fosfin cair terhadap mortalitas $T$. parvispinus

Persentase mortalitas tertinggi terjadi pada aplikasi fosfin cair konsentrasi 200 ppm pada semua waktu papar dan konsentrasi 175 ppm pada waktu papar 6 jam (Tabel 1). Perlakuan pada konsentrasi terendah (25 ppm) pada waktu papar 1 jam hanya memberikan persen mortalitas $56,0 \%$, namun terjadi kenaikan persentase mortalitas pada waktu papar 3 dan 6 jam berturut-turut menjadi $66,67 \%$ dan $70,67 \%$. Peningkatan mortalitas serangga uji terjadi pada semua perlakuan kecuali pada perlakuan konsentrasi 200 ppm yang memang sejak pemaparan 1 jam sudah menghasilkan mortalitas $100 \%$. Nilai $\mathrm{LC}_{50}$ dan $\mathrm{LC}_{95}$ terendah ditunjukan pada waktu papar 6 jam, yaitu berturutturut 17,32 dan 120,61 ppm (Tabel 2).

\section{Pengaruh fosfin cair terhadap kulitas bunga potong krisan}

Hasil pengamatan mortalitas pada uji validasi menunjukkan bahwa persentase mortalitas tertinggi (100\%) ditunjukan pada perlakuan konsentrasi 200 dan 250 ppm pada semua waktu papar $(1,3$, dan 6 jam) (Tabel 3). Sementara itu, pengaruh aplikasi fosfin cair terhadap kualitas fisik bunga potong yang diamati pada 1, 24, 48, dan 72 JSP pada semua perlakuan konsentrasi dan waktu papar tidak menunjukan perubahan kualitas fisik yang dibandingkan dengan kontrol (Gambar 1, 2, dan 3). Rata-rata nilai skoring yang didapatkan pada setiap perlakuan adalah 0 yang menunjukkan tidak terjadinya kelayuan atau kondisi lain yang berbeda dengan bunga pada perlakuan kontrol (0 ppm).

Tabel 1. Penduga parameter toksisitas fosfin cair terhadap mortalitas Thrips parvispinus pada beberapa waktu papar

\begin{tabular}{lcccc}
\hline $\begin{array}{l}\text { Waktu papar } \\
\text { (jam) }\end{array}$ & $a^{\mathrm{a}} \pm \mathrm{GB}^{\mathrm{b}}$ & $b^{\mathrm{c}} \pm \mathrm{GB}$ & $\begin{array}{c}\mathrm{LC}_{50}(\mathrm{ppm}) \\
(\mathrm{SK} 95 \%)\end{array}$ & $\begin{array}{c}\mathrm{LC}_{95}(\mathrm{ppm}) \\
(\mathrm{SK} 95 \%)^{\mathrm{d}}\end{array}$ \\
\hline 1 & $-2,96 \pm 0,41$ & $0,17 \pm 0,90$ & $\begin{array}{c}29,13 \\
(11,87-43,25)\end{array}$ & $\begin{array}{c}189,91 \\
(126,88-479,58)\end{array}$ \\
& & & 20,23 & 148,35 \\
3 & $-2,48 \pm 0,44$ & $0,19 \pm 0,10$ & $(6,40-32,43)$ & $(102,57-329,80)$ \\
& & & 17,32 & 120,61 \\
6 & $-2,42 \pm 0,46$ & $0,22 \pm 0,12$ & $(5,49-28,08)$ & $(86,46-230,91)$ \\
\hline
\end{tabular}

${ }^{\mathrm{a}} a$ : intersep regresi probit; ${ }^{\mathrm{b}} \mathrm{GB}$ : galat baku; ${ }^{\mathrm{c}} b$ : kemiringan regresi probit; ${ }^{\mathrm{d}} \mathrm{SK}$ : selang kepercayaan.

Tabel 2. Rata-rata persentase mortalitas Thrips parvispinus pada perlakuan beberapa konsentrasi fosfin cair pada waktu papar 1, 3, dan 6 jam

\begin{tabular}{cccc}
\hline $\begin{array}{l}\text { Perlakuan } \\
(\mathrm{ppm})\end{array}$ & \multicolumn{3}{c}{ Mortalitas $\pm \mathrm{SD}^{\mathrm{a}}(\%)^{\mathrm{b}}$} \\
\cline { 2 - 4 } & $1 \mathrm{jam}$ & \multicolumn{3}{c}{$\mathrm{jam}$} & $6 \mathrm{jam}$ \\
\hline 0 (Kontrol) & $0,0 \pm 0,0 \mathrm{e}$ & $0,0 \pm 0,0 \mathrm{f}$ & $0,0 \pm 0,0 \mathrm{f}$ \\
55 & $56,0 \pm 0,0 \mathrm{~d}$ & $66,7 \pm 2,3 \mathrm{e}$ & $70,7 \pm 2,3 \mathrm{e}$ \\
70 & $61,3 \pm 4,6 \mathrm{~d}$ & $70,7 \pm 2,3 \mathrm{e}$ & $74,7 \pm 2,3 \mathrm{e}$ \\
75 & $70,7 \pm 6,1 \mathrm{c}$ & $77,3 \pm 2,3 \mathrm{~d}$ & $84,0 \pm 4,0 \mathrm{~d}$ \\
100 & $78,7 \pm 2,3 \mathrm{c}$ & $89,3 \pm 2,3 \mathrm{c}$ & $92,0 \pm 0,0 \mathrm{c}$ \\
150 & $91,0 \pm 2,6 \mathrm{~b}$ & $92,0 \pm 0,0 \mathrm{bc}$ & $93,3 \pm 2,3 \mathrm{bc}$ \\
175 & $94,7 \pm 2,3 \mathrm{ab}$ & $97,3 \pm 2,3 \mathrm{ab}$ & $98,7 \pm 2,3 \mathrm{ab}$ \\
200 & $97,3 \pm 2,3 \mathrm{ab}$ & $98,7 \pm 2,3 \mathrm{a}$ & $100,0 \pm 0,0 \mathrm{a}$ \\
\hline
\end{tabular}

a: Standard deviasi

${ }^{\mathrm{b}}$ : Rata-rata persentase mortalitas yang diikuti huruf yang sama menunjukan tidak berbeda nyata berdasarkan uji Tukey taraf $5 \%$. 
Tabel 3. Rata-rata persentase mortalitas Thrips parvispinus pada perlakuan fosfin cair dengan beberapa waktu papar pada bunga krisan

\begin{tabular}{|c|c|c|c|}
\hline \multirow{2}{*}{$\begin{array}{l}\text { Perlakuan } \\
\text { (ppm) }\end{array}$} & \multicolumn{3}{|c|}{ Mortalitas $\pm \mathrm{SD}^{\mathrm{a}}(\%)^{\mathrm{b}}$} \\
\hline & $1 \mathrm{jam}$ & 3 jam & $6 \mathrm{jam}$ \\
\hline 0 (Kontrol) & $0,0 \pm 0,0 \mathrm{~b}$ & $0,0 \pm 0,0 \mathrm{~b}$ & $0,0 \pm 0,0 \mathrm{~b}$ \\
\hline 175 & $96,0 \pm 0,0 \mathrm{a}$ & $98,7 \pm 2,3 \mathrm{a}$ & $98,27 \pm 2,3 \mathrm{a}$ \\
\hline 200 & $100,0 \pm 0,0 \mathrm{a}$ & $100,0 \pm 0,0 \mathrm{a}$ & $100,0 \pm 0,0 \mathrm{a}$ \\
\hline 250 & $100,0 \pm 0,0 \mathrm{a}$ & $100,0 \pm 0,0 \mathrm{a}$ & $100,0 \pm 0,0 \mathrm{a}$ \\
\hline
\end{tabular}

a: Standar deviasi

b: Rata-rata persentase mortalitas yang diikuti oleh huruf yang sama pada kolom yang sama menunjukan tidak berbeda nyata berdasarkan uji tukey taraf $5 \%$.

\section{PEMBAHASAN}

Serangga uji trips dari lapangan yang diidentifikasi memiliki ciri morfologi yang sama berdasarkan Sartiami \& Mound (2013) sehingga spesies trips yang digunakan dalam penelitian ini adalah $T$. parvispinus. Ketepatan serangga yang digunakan dalam pengujian toksisitas suatu insektisida akan memberikan informasi yang benar berkaitan dengan hasil pengujian termasuk dalam pengujian toksisitas fosfin formulasi cair.

Aplikasi fosfin formulasi cair terhadap $T$. parvispinus pada kisaran konsentrasi 200-350 ppm pada uji pendahuluan memberikan persentase kematian $100 \%$ pada semua konsentrasi. Liu (2008) melaporkan bahwa perlakuan fumigasi di atas $250 \mathrm{ppm}$ dengan lama waktu di atas 18 jam pada suhu $2{ }^{\circ} \mathrm{C}$ efektif dalam mengendalikan F. occidentalis. Hasil penelitian terhadap $T$. parvispinus memperlihatkan respons trips sangat sensitif terhadap fosfin. Karunatratne et al. (1997) melaporkan bahwa fumigasi pada trips akan lebih cepat memberikan pengaruh kematian dibandingkan dengan serangga lain, seperti kutu daun dan larva lepidoptera pada suhu di atas $24^{\circ} \mathrm{C}$.

Pada perlakuan dengan 3 waktu papar $(1,3$, dan 6 jam) dengan 8 konsentrasi $(200,175,150$, $125,100,75,50,25 \mathrm{ppm}$ ) dan kontrol pada suhu berkisar $26-32{ }^{\circ} \mathrm{C}$, terlihat bahwa peningkatan konsentrasi fosfin cair akan meningkatkan mortalitas trips. Demikian juga halnya dengan waktu papar, waktu papar semakin lama maka mortalitas trips semakin meningkat. Pada konsentrasi antara 25-175 ppm dengan waktu papar 1 jam menunjukkan tidak terdapat konsentrasi perlakuan yang memberikan persentase mortalitas sebesar $100 \%$. Hal ini diakibatkan karena kurang lamanya waktu papar fumigasi atau kurang tingginya konsentrasi fumigan yang digunakan. Namun demikian, selain faktor konsentrasi dan waktu papar, faktor lain yang dapat berpengaruh adalah suhu. Pengujian atau perlakuan dengan suhu yang lebih tinggi dapat meningkatkan mortalitas. Suhu yang lebih tinggi akan meningkatkan keaktifan serangga. Semakin aktif serangga akan semakin meningkatkan aktifitas respirasi serangga sehingga menyebabkan serangga menghirup gas fosfin lebih banyak. Kemudian perlakuan suhu tinggi dapat berpengaruh langsung pada denaturasi/merusak sifat protein pada serangga (Karunaratne et al. 1997).

Pengaruh waktu papar memiliki dampak terhadap toksisitas fosfin cair yang ditunjukkan oleh nilai $\mathrm{LC}_{50}$ dan $\mathrm{LC}_{95}$. Semakin lama waktu papar maka nilai LC akan lebih rendah dibandingkan dengan waktu papar yang lebih singkat. Nilai $\mathrm{LC}_{50}$ untuk masing-masing waktu papar 1, 3, dan 6 jam berturut-turut adalah 29,13; 20,23 dan 17,32 ppm. Terlihat bahwa pada konsentrasi 17,32 ppm dengan waktu papar 6 jam menunjukan mortalitas sebesar $50 \%$ sementara waktu papar 1 jam membutuhkan konsentrasi lebih tinggi, yaitu 29,13 ppm. Dengan demikian, terdapat keterkaitan antara waktu papar dan konsentrasi. Menurut Hole et al. (1976) fumigasi menggunakan fosfin dengan konsentrasi rendah pada waktu papar lebih lama akan lebih efektif dibandingkan dengan konsentrasi fosfin yang tinggi pada waktu papar yang singkat. Penentuan konsentrasi fosfin bergantung pada berbagai faktor, antara lain kondisi lingkungan, penyimpanan, lama perlakuan, dan jenis serangga utama yang dikendalikan (TDRI 1983).

Pada uji validasi, aplikasi fosfin formulasi cair konsentrasi 200 ppm dengan waktu papar 


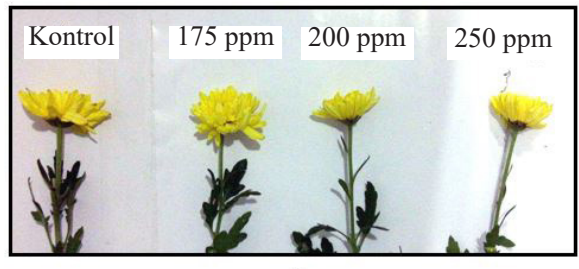

A

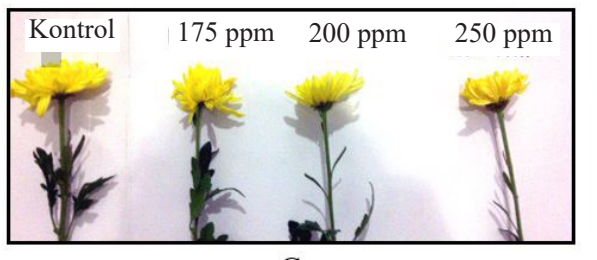

C

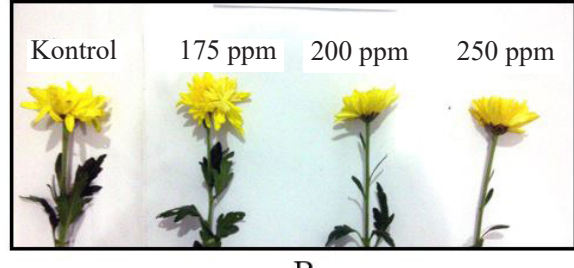

B

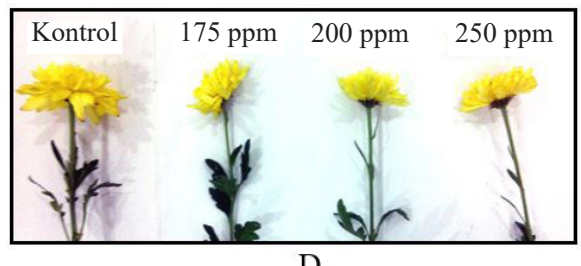

Gambar 1. Penampilan bunga potong krisan yang dipaparkan fumigan fosfin selama 1 jam pada pengamatan A: 1 JSP; B: 24 JSP; C: 48 JSP; dan D: 72 JSP. JSP: jam setelah perlakuan.

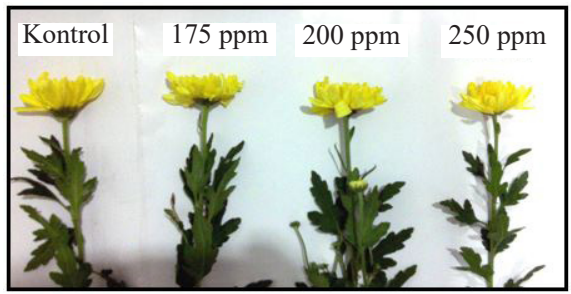

A

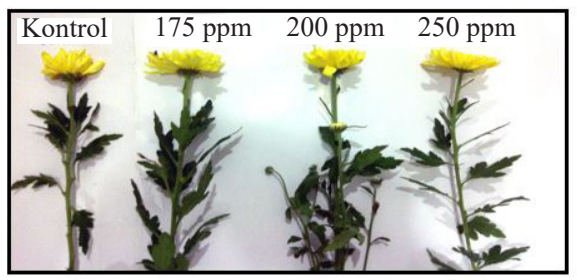

$\mathrm{C}$

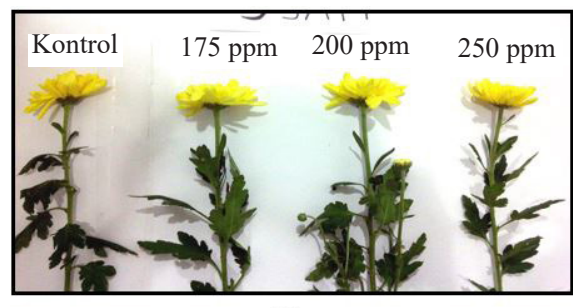

$\mathrm{B}$

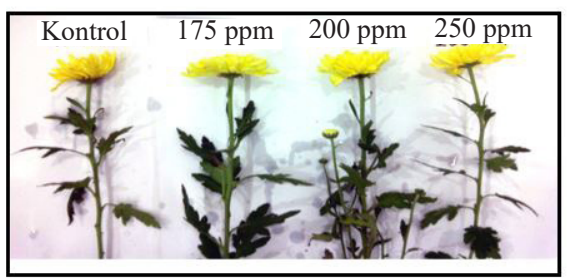

$\mathrm{D}$

Gambar 2. Penampilan bunga potong krisan yang dipaparkan fumigan fosfin selama 3 jam pada pengamatan A: 1 JSP; B: 24 JSP; C: 48 JSP; dan D: 72 JSP. JSP: jam setelah perlakuan.
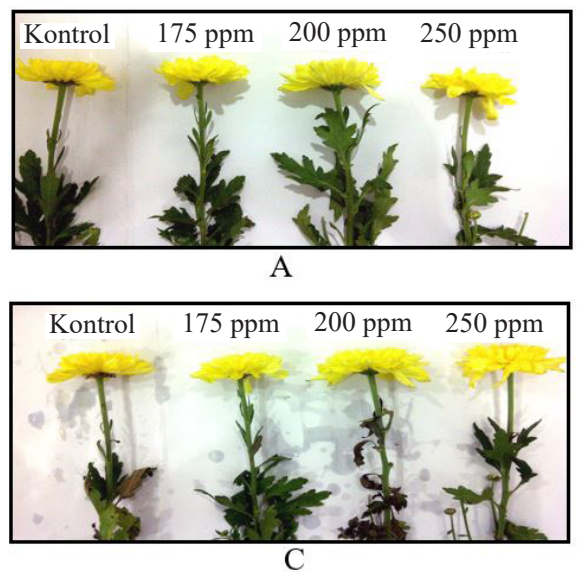
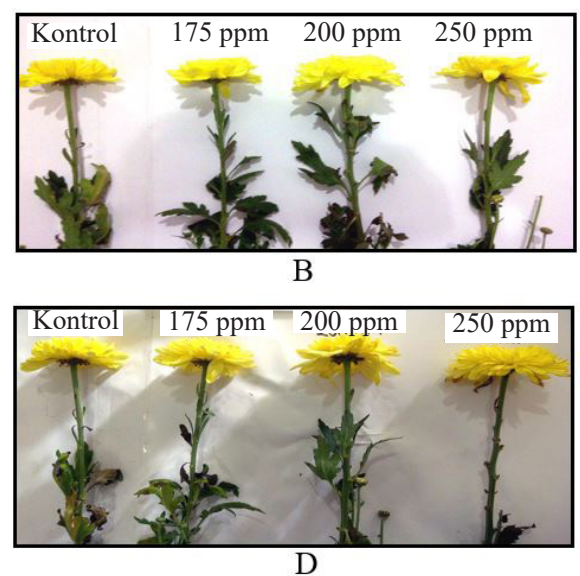

Gambar 3. Penampilan bunga potong krisan yang dipaparkan fumigan fosfin selama 6 jam pada pengamatan A: 1 JSP; B: 24 JSP; C: 48 JSP; dan D: 72 JSP; JSP: jam setelah perlakuan. 
1 jam menunjukan kematian $100 \%$ dan hasil ini tetap konsisten dengan perlakuan sebelumnya yang menghasilkan persentase mortalitas $100 \%$. Pada perlakuan konsentrasi 200 ppm tidak berdampak pada kualitas bunga potong krisan baik itu pada pengamatan 1, 24, 48, dan 72 JSP. Menurut Barantan (2013) terdapat efek sinergis cara kerja antara fosfin cair dan $\mathrm{CO}_{2}$ ketika digunakan bersama. Disamping itu, sifat stabilitas dari konsentrasi fosfin cair lebih mudah dipertahankan selama fumigasi jika dibandingkan dengan fosfin padat. $\mathrm{CO}_{2}$ mampu meningkatkan pernapasan serangga sehingga spirakel akan terbuka ketika serangga bernapas sehingga akan mempercepat laju konsumsi fosfin formulasi cair. Hal ini menyebabkan penggunaan fosfin formulasi cair lebih efesien untuk mencapai hasil yang diinginkan dan waktu papar aplikasi fosfin cair dapat dipersingkat.

Tidak terjadinya penurunan kualitas bunga potong krisan yang diaplikasikan fosfin cair dilaporkan juga oleh peneliti lain. Karunaratne et al. (1997) menyatakan bahwa perlakuan fumigasi fosfin pada konsentrasi di bawah $4.000 \mu 1 / 1$ pada bunga tulip dengan waktu papar 2 dan 4 jam menunjukan kualitas bunga yang sama atau tidak berbeda dengan bunga yang tidak diberi perlakuan (kontrol). Hasil yang sama dilaporkan juga oleh Zhang et al. (2012) bahwa bunga krisan yang diperlakukan dengan fosfin cair pada konsentrasi 0,$76 ; 1,52 ; 3,04 \mathrm{mg} / \mathrm{l}$ dengan waktu papar 2, 5, 8, dan 11 hari pada temperatur $2{ }^{\circ} \mathrm{C}$ tidak menunjukan kerusakan pada bunga.

Pada suhu lebih tinggi waktu papar aplikasi fosfin cair dapat lebih cepat karena aktivitas serangga akan meningkat dibandingkan dengan perlakuan pada suhu rendah. Respirasi serangga pada suhu lebih tinggi akan lebih cepat dan gas fosfin cair yang dapat masuk ke dalam tubuh serangga akan lebih banyak sehingga dapat mempercepat laju mortalitas. Kondisi optimal untuk fumigasi fosfin cair, yaitu pada suhu $\geq 26{ }^{\circ} \mathrm{C}$ (Song et al. 2011).

Kualitas bunga setelah perlakuan masih tampak normal karena fosfin cair yang digunakan merupakan campuran $2 \%$ fosfin dan $98 \% \mathrm{CO}_{2}$. $\mathrm{CO}_{2}$ dibutuhkan oleh tanaman dalam fotosintesis atau asimilasi karbon. Konsentrasi gas $\mathrm{CO}_{2}$ yang tinggi dapat memperpanjang masa simpan dengan cara menghambat proses respirasi (Salunkhe et al. 1990). Pada bunga potong, etilen dapat merangsang gugurnya kuncup bunga, sementara $\mathrm{CO}_{2}$ bekerja secara berlawanan dengan kerja etilen (Wills et al. 1989). Konsentrasi $\mathrm{CO}_{2}$ yang tinggi pada fosfin cair dapat menghambat proses biokimia, yaitu terhambatnya sintesa etilen.

\section{KESIMPULAN}

Fumigasi dengan fosfin formulasi cair terhadap T. parvispinus pada bunga potong krisan efektif dilakukan pada konsentrasi 200 ppm dengan lama waktu papar selama minimal 1 jam dan tidak lebih dari 6 jam, yang menyebabkan mortalitas sebesar $100 \%$. Pada konsentrasi dan waktu ini tidak memberikan pengaruh negatif terhadap kualitas bunga potong krisan.

\section{DAFTAR PUSTAKA}

[Barantan] Badan Karantina Pertanian. 2013. Keputusan Kepala Badan Karantina Pertanian Nomor 1645 Tahun 2003 tentang Standar Teknis Fosfin Formulasi Cair. Jakarta: DEPTAN.

[BPS] Badan Pusat Statistik. 2013. Analisa Komoditi Ekspor 2007-2012 Sektor Pertanian, Industri dan Pembangunan. Jakarta: BPS.

Helen ED, Glenys MW. 2009. An improved method for rearing western flower thrips Frankliniella occidentalis. Florida Entomologist 92:664-666. doi: doi:http://dx. doi.org/10.1653/024.092.0424.

Hole BD, Bell CH, Mills KA, Goodship G. 1976. The toxicity of phosphin to all developmental stages of thirteen species of stored product beetles. Journal of Stored Products Research 12:235-244.

Horn F, Horn P, Sullivan J. 2005. Current practice in fresh fruit fumigation with phosphine in Chile. In: Obenauf GL (Ed.), Proceedings of 2005 Annual Research Conference on Methyl Bromide Alternatives and Emission Reductions (San Diego, California, 30 October-30 November 2005). pp. 61-63. San Diego: Methyl Bromide Alternatives Outreach.

Karunaratne C, Moore GA, Jones R, Ryan R. 1997. Phosphine and its effect on some common insects in cut flowers. Postharvest Biology and Technology 10:255-262. 
Laksanawati HD. 1996. Daya guna mikrobia Beauveria dan Verticilium dalam mengendalikan Thrips tabaci pada bawang putih. Jurnal Hortikultura 6:55-66.

LeOra Software. 1987. POLO-PC User's Guide. Petaluma: LeOra Software.

Liu YB. 2008. Low temperature phosphine fumigation for postharvest control of western flower thrips (Thysanopthera; Thripidae) on lettuce, broccoli, asparagus, and strawberry. Journal of Economic Entomology. 101:1786-1791. doi: doi: http://dx.doi.org/10.1603/0022-0493101.6.1786.

Maha M. 1997. Iradiasi sebagai salah satu alternatif untuk perlakuan karantina. Prosiding Seminar. Tersedia di: http://repository.ipb. ac.id/bitstream/handle/123456789/26601/ Seminar_Nasional_Teknologi_Pangan-50. pdf?sequence $=1 \&$ isAllowed $=\mathrm{y}[$ diakses 2 Maret 2015].

[Pusdatin] Pusat Data dan Sistem Informasi Pertanian. 2014. Outlook Komoditi Krisan. Jakarta: Sekretariat Jenderal, Kementerian Pertanian.

Sartiami D, Mound LA. 2013. Identification of the terebrantian thrips (Insecta, Thysanoptera) associated with cultivated plants in Java, Indonesia. ZooKeys 306:1-21.
Salunkhe DK, Bhat NR, Desai BB. 1990. Postharvest Biotechnologhy of Flowers and Ornamental Plants. Berlin: Springer-Verlag.

Smith RC. 1989. Plant Resistant to Insect. Idoho: Departement of Plant. Soil and Entomological Sciences. University of Idoho Moscow.

Song XH, Wang PP, Zhang HY. 2011. Phosphine resistance in Rhyzoperta dominica (Fabricius) (Coleoptera: Bostrichidae) from different geographical population in China. African Journal of Biotechnology 10:16367-16373.

[TDRI] Tropical Development Research Institute. 1983. Food Storage Manual. England: Word Food Programme. FOA \& TDRI.

Wills RBH, McGlasson WB, Graham D, Lee TH, Hall EG. 1989. An Introduction to The Physiology and Handling of Fruits, and Vegetables. In: Food Storage Manual. New York: Van Nostrand Reinhold.

Zhang F, Wang Y, Liu T, Li L, Li T. 2012. Effects of low temperature phosphine fumigation on post harvest quality of white chrysanthemum 'Dabaiju'. Scientia Horticulturae 142:92-97. doi: http://dx.doi.org/10.1016/j.scienta.2012.05.005. 